\title{
Information Literacy and Doctoral Students: Avatars and Educators Collaborate for Online Distance Learning
}

\author{
Elizabeth Rhodes and Lynette Ralph \\ Southeastern Louisiana University, Hammond, LA, USA
}

\author{
erhodes@selu.edu; Iralph@selu.edu
}

\begin{abstract}
This paper describes a project in which an educational technology faculty member and a librarian collaborated to provide information literacy to doctoral students. The collaboration focused on meeting the needs of these graduate students. In addition to a required a face-to-face experience, these students with no prior experience of technology were exposed to the BlackBoard Virtual classroom and the virtual world sites of Second Life (SL). Through this project, the collaborators used the multi-user virtual environment of SL to demonstrate how information literacy, teaching and discussion groups can be successfully applied in a virtual environment. Both the librarian and educational technology faculty member embraced this delivery model to impart information literacy to doctoral students.
\end{abstract}

Keywords: Information literacy, doctoral students, distance learning, library instruction

\section{Introduction}

Information Literacy can be defined as a set of skills that enable an individual to understand, find, evaluate and use information effectively. It is essential for lifelong learning. Information literacy service for graduate students is not usually heavily promoted. Faculty members either assume that their graduate students arrive at school competent in research skills, or that these students should discover how to effectively conduct the research process through self-discovery. Consequently, few library instruction services are provided for graduate students.

The reality is that graduate students, like their undergraduate counterparts, are derived from a wide variety of educational backgrounds, and thus frequently have knowledge gaps about finding and using information that can impede their success as researchers (Rempel \& Davidson, 2008). The emergence of the Internet and the explosion of information resources have led to increased graduate student frustration and research anxiety (Lampert, 2005). The School of Education and the Sims Library are working to reduce this anxiety by providing students with integrated curricu-

Material published as part of this publication, either on-line or in print, is copyrighted by the Informing Science Institute. Permission to make digital or paper copy of part or all of these works for personal or classroom use is granted without fee provided that the copies are not made or distributed for profit or commercial advantage AND that copies 1) bear this notice in full and 2) give the full citation on the first page. It is permissible to abstract these works so long as credit is given. To copy in all other cases or to republish or to post on a server or to redistribute to lists requires specific permission and payment of a fee. Contact 0HPublisher@InformingScience.org to request redistribution permission. lum information literacy training within their studies. Unfortunately, specific recommendations and successful strategies for infusing subject specific information literacy skills into graduate studies are not prevalent in information literacy literature. This article could contribute to this vacuum. The critical need for collaboration between librarians, educational technology faculty and discipline faculty member is clear, and em- 
phasizes the need for the incorporation of information literacy skills training into the graduate curriculum. This research describes how the collaborative effort evolved, showing movement from an interpersonal to synergetic level as proposed by Raspa and Ward (2000). According to Raspa and Ward, the interpersonal level of collaboration is where "the partners begin to explore both personal and interdisciplinary areas of interest and may undertake small projects" (p. 12).

\section{Literature Review}

The library literature provides a wealth of information supporting collaboration of faculty and librarians in providing information literacy. O'Sullivan (2002) posits that information literacy skills have been taught for decades. But recently, the principles and concepts have assumed new urgency because they are increasingly perceived as significant "new economy" skills (p.7). Rockman (2004) provided a number of case studies that document faculty and librarian collaboration to integrate library instruction into the curricula of various academic disciplines. McAskill (2008) points out that the rapid advances in information technology have led to greater pressure on academic librarians and teaching faculty to incorporate information literacy skills into the curriculum. Hollister (2008) discussed how librarian-faculty collaboration integrated library instruction into the University of Buffalo's world civilization curriculum. Most of the literature and guidelines published by associations, focus on undergraduate studies. Lampert (2005), however, shared how Educational Psychology and Counseling faculty and librarians of California State worked to provide graduate students with integrated curriculum information literacy training throughout their studies.

The importance of the librarian-faculty collaboration cannot be overemphasized. It is critical to student success. While librarians have successfully contributed to the information literacy programs on campuses, it has become necessary for them to redouble their efforts (Sugarman \& Thaxton, 2008). Thus the traditional one-shot bibliographic instruction session, even though still conducted, no longer meets the needs of providing information literacy to students (Li, 2007) Sims Library has encouraged librarian-faculty collaboration through participation in the liaison program. Greater student success could be achieved with the collaboration of the librarian, the educational technology faculty and the discipline faculty. This combination will arm the graduate student with the ability "to find, evaluate, analyze, communicate and use information to solve problems, create new ideas, make informed decisions, and turn data into meaning" (Sugarman \& Thaxton, 2008).

\section{Statement of the Problem}

Graduate doctoral students at Southeastern Louisiana University (Southeastern) in Educational Leadership need both information literacy skills and technological know-how. The average graduate student in this group is returning to school after an extended period, and therefore lacking the appropriate sets of skills required in the digital age. For example, these students use course readings, Google and Wikipedia for their primary sources. Since these limited sources are inadequate, the students may begin the research process engaged and curious, but become frustrated and overwhelmed as it progresses. Additionally, Southeastern students are served in cohorts and don't have many opportunities to come to campus and therefore interact with other cohorts. Concomitantly, the doctoral students who are working professionals in K-12 schools are managers of learning environments for students who use these tools with ease. It is imperative then that leaders of tomorrow's schools be familiar with these tools and their pedagogical value. As specialists in information literacy and educational technology, the researchers who are initiating this scientific study are interested in collaborating to discover information that can bring knowledge and insight to this subject. 
Building an online learning community situated in cyberspace may be the only way to build a virtual architecture supporting the disparate remote communities of learners and the faculty who teach them. In addition, a virtual library may be the perfect situ for the information literacy resources needed for successful completion of their program. As a result, project collaborators would like to test the advantages of situating this group of doctoral candidates in SL, a free 3D virtual world where users can socialize, connect and create using free voice and text chat, as an online learning model.

The goal of this ongoing research is to assess the value of exposing doctoral students to informational literacy through the use of technology. In support of achieving this goal, the following research questions were asked:

(1) Will collaboration of faculty and librarian facilitate the delivery of information literacy to the doctoral students?

(2) Will non-technology savvy doctoral students acquire information literacy skills through the use of virtual learning environments?

(3) Will the use of avatars contribute to the enhancement of the learning experience?

\section{Institutional Context}

Southeastern Louisiana University (Southeastern) is located approximately 50 miles North of New Orleans. This university began in 1925 as a grass roots movement by the people of Hammond and the surrounding area. Southeastern has since grown to meet the evolving needs of southeast Louisiana and the Florida parishes and now has an enrollment of approximately 15,000. Southeastern is largely a commuter campus and considered the second largest provider of distance education in Louisiana In fall 2006 Southeastern added its first doctoral program in Educational Leadership, offered in consortium with the University of Louisiana-Lafayette. (University Profile 2006)

\section{Background to Sims Memorial Library}

Sims Memorial Library (Sims) is a medium-sized academic library of Southeastern. This library's procedures are based on best practices and it has consistently remained on the cutting edge of technology. Sims began its chat reference service in the Fall semester of 2002. In the Spring of 2005, Sims was the first library in the country to initiate a "Text A Librarian" service that allows its students, faculty and staff to utilize their cell phones and send reference questions to and receive answers from their librarians. To reach out to the students who do not come into the library, the reference librarians have taken their laptops and "roamed" the campus, sitting at the student union and other high trafficked areas where they answered questions or performed online searches. Recently, the library joined Facebook and Twitter and invited students, faculty and staff to communicate their needs to the library. In Fall 2008, Sims created a presence in Second Life. Second Life then is yet another face of the Sims and an opportunity to provide additional service to the distance learners. Sims librarians believe that SL offers a built-in redundancy for distance learners.

\section{Second Life}

Second Life is an Internet-based open source three dimensional virtual world platform developed by Linden Research Inc., and launched on June 23, 2003. It is a Multi user Virtual Environment (MUVE) accessed by many users simultaneously and facilitating the interaction between people. "Second Life is probably the best-known example of a virtual world that can be used for a wide variety of purposes" (Kelly, 2008, p. 30). From the time it was launched in 2003, over 15 million 
accounts have been registered in SL. The Gartner Research Group opined, "By 2011 about 80\% of regular Internet users will have a 3-D Web presence."

On the surface, SL looks like a video game because it uses an interface similar to PC gaming. However, there are no rules, objectives, points or levels to attain. The environment is totally designed, built and scripted by the residents who retain intellectual property rights of their creations. These intellectual property rights owners often sell their creations, usually in unmanned kiosks or stores. The SL currency is the Linden Dollar. At the time of writing, one US Dollar is valued at

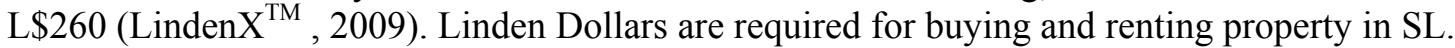

Some clothing can be obtained free of charge, while other clothing could be purchased using Linden Dollars. The users of SL are called residents. These residents create a customizable three dimensional cartoon representations of themselves called avatars. Parker (2008) observed that approximately 50,000 avatars are present in SL at any given time.

The basic avatar can be animal or human in appearance. It may also be of either gender, can have a wide range of physical attributes, and can interact with the game environment and other avatars. Interactions occur by typing in a chat box, instant messaging (IM), or via voice with the use of a microphone. Thus "SL gives the opportunity for avatars to have a real-life kind of exchange and get the feeling of personal contact that is not present in email or IM" (Godwin, 2008, p. 171). Libraries were drawn to the new paradigm almost immediately. As Kitty Pope, Executive Director of the Alliance Library System (ALS) said, "Second Life has malls, residential neighborhoods, online communities - why not a library?" (Hawkins, 2006). SL has definite advantages for librarians and more specifically for librarians interested in providing a presence in the virtual world.

\section{Information Literacy Activities by Sims Library in Second Life}

Grassian (2007) suggested that SL librarians can use SL as a way to incorporate information literacy into "curricula, research, and course assignments as they are designed" (p. 86). Several Southeastern faculty members embraced the idea of teaching in SL. In the Fall of 2008, there was a Health Information Fair for Nursing students. Sims library staff utilized this opportunity to provide information literacy to the nursing students. In the fall of 2009, two Southeastern classes were at least partially taught in SL: ENGL 315 (Performing Virtual Identities), and ENGL 651 (History of the Book). Library instruction was provided for each of these classes by Sims' librarians. A class taught in the spring semester of 2010 in an undergraduate educational technology course, as well as a BI class for doctoral students in the Educational Leadership program, all received instruction from Sims' librarians. In April, there will be in SL, a presentation by a foreign language and literature faculty member and a clinical demonstration by a Nursing faculty member. Several Sims librarians will participate by covering the desk in their SL library, providing relevant information and one-on-one assistance.

\section{Issues Challenges and Concerns Influencing Use of Second Life}

\section{Hardware}

Appropriate hardware and software are required to run SL successfully. Minimum recommended requirements include an Internet connection using Cable or DSL. (SL is not compatible with dialup Internet; satellite Internet, and some wireless Internet services.) The Operating System must be Windows XP (Service Pack 2) or Windows 2000 (Service Pack 4). The computer processor must be $2 \mathrm{GHz}$ or better. The computer memory must be 1 gig or larger, and the computer must have a graphics card. Mac users need the OS X 10.3.8 or later operating system, the $1 \mathrm{GHz}$ G4 or better 
computer processor, and 512MB or greater computer memory. Systems that do not meet these requirements may not be able to participate in SL. Alternatively, failure to have the adequate hardware and software can result in embarrassing experiences. For example, an avatar may appear naked in a room full of people as it awaits the downloading of its clothing (Parker, 2008).

\section{Learning Curve}

SL requires some technological savvy. It is expected that the learning trajectory for the doctoral candidates to use this tool will be high, despite the fact that as school leaders, they are highly motivated to become familiar with virtual environments and social networking sites - common tools used by students in the schools they administer. Exposing administrators to social networking tools can only foster their understanding of the "techno - wonderluster" for the generation of students with whom they work. The learning curve to function effectively in SL is quite steep. Basic activities such as walking around without falling or bumping into things; simple gestures such as waving, sitting, or laughing are all very challenging initially. It can become a real crisis to stop an avatar from dancing, or to make it turn around instead of flying upwards. There are a number of challenges to this collaboration, including time constraints, availability, faculty's willingness to surrender time in an already limited schedule and the learning trajectory of advanced technological skills. However these can be overcome based on the type of programs employed.

\section{The Research Method}

The descriptive research design method was chosen to conduct this study. Descriptive research provides "a clear, accurate description of individuals, events, or processes" (Gall, Gall, \& Borg, 1999, p.172). A descriptive study also determines and reports the way things are. Gay and Airasian (2000) pointed out that descriptive research involves collecting data in order to answer questions concerning the current status of the subject of the study. This study, through the use of the research questions, assessed the effectiveness of the virtual classroom and Second Life.

\section{Needs Assessment}

A focus group of 12 students was utilized to assess the needs of the graduate students. Initially, the 12 students, who were also considered the pilot group, received a face to face session in which a number of information literacy topics were covered (see Appendix A). Next, these students were introduced to the virtual classroom, a feature in Blackboard (course management software) that allows for synchronous communication. The virtual classroom session had a twofold purpose. The first purpose was to evaluate the face to face session in which a librarian introduced them to information literacy concepts (see Appendix B, Part 1). They were then asked to identify the technology tools with which they were unfamiliar, and to state the tools with which they would like to be exposed (see Appendix B, part 2). Based on the results of the discussion, an overwhelming number $(85 \%)$ of the students expressed interest in Second Life. These findings contributed to the design of the second phase of the research.

The needs assessment revealed the following: 1) Due to recent fiscal constraints the library hours are not convenient for working professionals; 2) Graduate faculty intentionally and strongly encourage a community of learners among candidates, based on the fundamental belief in learning as a social practice (Wenger 1998). There are few opportunities for collaboration among a community of learners in Internet (online) courses. Graduate students expressed a need for a collaborative online workspace to meet. 3) The needs assessment also revealed that the doctoral candidates had not been exposed to sophisticated online collaborative tools, such as, the virtual classroom, wikis, blogs, virtual reality sites, collaborative or social networking tools. 
The second phase of the research involved identifying a second group of students $(\mathrm{N}=18)$ that would experience a face-to face session with a librarian, a virtual classroom experience, and a Second Life experience, which involved the creation of an avatar - a customizable three dimensional cartoon representations of the user. This data has been collected and compiled, but not yet been analyzed. It is expected that the researchers will be able to present their findings at the time of the conference. Findings will include answers to the research questions.

The research methodology utilized both qualitative and quantitative measures of student perceptions of SL and the Virtual Classroom, in general, as a pedagogical tool and, in particular, as a means to understanding the subject of information literacy. The following qualitative data was analyzed: 1) transcripts of the virtual classroom sessions, emails of the researchers, student emails, and field notes of the researchers. The following quantitative data was analyzed; a survey of student perceptions of the Second Life experience in general, a survey instrument that compares the two delivery options (face-to-face and online in Second Life) for transfer of knowledge about information literacy and the facility of use of the two tools.

\section{Preliminary Observations and Lessons Learned}

Although the analysis of the data collected in this research study is not yet complete, there are some preliminary observations that are noteworthy. With respect to the first research question, researcher field notes reveal that faculty and librarian collaborated in the proposal of this project, the implementation of the research and will in the next few weeks analyze all the data collected in this project. An analysis of the survey data will determine whether this collaboration (as perceived by students) facilitated the delivery of information literacy to Southeastern doctoral students. With respect to the second research question, anecdotal evidence revealed that students reported increased confidence in the use of technology tools, including manipulation of virtual learning environments. Researchers observed that students were active participants in the virtual classroom and expressed appreciation for the convenience of meeting in this manner for academic purposes. Students were enthusiastically receptive to their initial experiences in the Virtual Classroom and in Second Life. All were eager to participate in the orientation process despite the learning curve. And with respect to the third research question, researcher observations revealed that students were highly motivated to create avatars in Second Life that could "perform" the functions necessary for full participation in the experience. However, further analysis of the data will be required to determine if the creation of the avatar had any pedagogical value and if it contributed to the learning experience as perceived by the students.

\section{Conclusion}

Hartshorne (2004) emphasizes that preparing future teachers to meet information technology and research challenges requires the collaborative development of instructional strategies by both education faculty and academic librarians. Library science literature and guidelines published by associations focus on undergraduate studies programs. However, graduate students are clearly in need of information literacy skills building opportunities - especially through programs that target discipline specific information resources and retrieval skills. This article discusses the dynamic librarian-faculty collaborative process at Southeastern Louisiana University that integrated discipline specific information literacy skills instruction assessment and educational technology into the campus' Doctoral program. Because it is not convenient for these doctoral students to meet regularly on the campus at a time when they can have face-to-face library instruction, alternate measures must be considered. The virtual classroom was utilized and proved to be effective. However, as a group of leaders faced with the education of a generation accustomed to gaming, the virtual world of SL offered a rare opportunity for them to step outside the box, into the role of 
their avatars and interact with the avatars of their faculty members and the librarian, the educators who had collaborated to make this experience possible.

\section{References}

Bhavnagri, N. P., \& Bielat, V. (2005). Faculty-librarian collaboration to teach research skills: Electronic symbiosis. In S. B. Kraat (Ed.). Relationships between Teaching Faculty and Teaching Librarians. Philadelphia, PA: Haworth Information Press.

Gall, M. D., Gall, J. P., \& Borg, W.R. (1995). Educational research: An introduction (8th ed.). New York, N.Y.: Longman Inc.

Gay, L. R., \& Airasian, P. (2000). Educational research (6th ed.). Upper Saddle River, N.J.: Merrill.

Godwin, P. (2008). Conclusion. In P. Godwin \& J. Parker (Eds.). Information literacy meets Library 2.0 (pp. 165-181). London: Facet Publishing.

Grassian, E., \& Truman, R. B. (2007). Stumbling, bumbling, teleporting and flying.librarian avatars in Second Life. Reference Services Review, 35, 84-89. doi 10.1108/00907320710729373

Hartshorne, R. (2004). Preparing preservice and inservice teachers with technology: An examination of types of school-university collaborations. In R. Ferdig et al. (Eds.), Proceedings of Society for Information Technology \& Teacher Education International Conference 2004 (pp. 2235-2240). Retrieved from http://www.editlib.org/noaccess/14776

Hollister, C.V. (2008). Meeting them where they are: Library instruction for today's students in the world civilizations course. Public Services quarterly, 4(1), 15-27.

Kelly, B. (2008). Library 2.0 and information literacy: The tools. In P. Godwin \& J. Parker (Eds.), Information literacy meets Library 2.0 (pp. 19-35). London: Facet Publishing.

Lampert, L. (2005). "Getting Psyched" about information literacy: A successful faculty-librarian collaboration for educational psychology and counseling. In S. B. Kraat (Ed.), Relationships between Teaching Faculty and Teaching Librarians. Philadelphia, PA: Haworth Information Press.

$\mathrm{Li}, \mathrm{H}$. (2007). Information literacy and librarian-faculty collaboration: A model for success. Chinese Librarianship, 24, 2. Retrieved from http://search.ebscohost.com

McAskill, W. (2008). Information literacy: The leadership role of the academic librarian. College Quarterly, 11(1), 1-15.

O'Sullivan, C. (2002). Is information literacy relevant in the real world? Reference Services Review, 30(1), 7-14. doi 10.1108/00907326210416492.

Raspa, R. \& Ward, D. (2000). Listening for collaboration: Faculty and librarians working together. In The collaborative imperatives: Librarians and faculty working together in the information universe. Chicago, IL: Association of College and Research Libraries.

Rempel, H. G., \& Davidson, J. (2008). Providing information literacy instruction to graduate students through literature review workshops. Retrieved from http://www.isti.org/08-winter/refereed2.html

Rockman, I. F. (2004). Integrating information literacy into the learning outcomes of academic disciplines. College and Research Libraries News, 64(9), 612-615.

Sugarman, T., \& Thaxton, M. L. (2008, June). Making it happen: librarian-faculty collaboration to improve student learning. Paper presented at the South Carolina Library Assn. College \& University Annual Workshop. Retrieved from: http://works.bepress.com/tammy_sugarman/6

Wenger, E. (1998). Communities of practice: Learning, meaning, and identity. Cambridge, England: Cambridge University Press. 


\section{Appendix A \\ Doctoral Students' Orientation \\ October 24, 2009}

1. Tour of Library

2. Overview of Library Services and Resources

3. Accessing Resources

4. Selecting the best resource to use to meet an information need, not just those that are most convenient or familiar.

5. Applying critical evaluation and synthesis of selected sources

6. Citing sources appropriately and accurately.

7. Managing Resources - Endnotes.

Services - Obtaining resources not owned by Library
a. Interlibrary Loan -Illiad
b. LALINC card
c. Research Assistance available - Ask a Librarian, texting, RCS
(Research Consulting Services- one-on-one)
d. Printing.

\section{Appendix B Interview Protocol November 12, 2009}

Part 1- Experience with Librarian's Orientation

Was it beneficial in your work as a doctoral student? What did you learn?

What was the most beneficial?

What was the least beneficial?

What aspect of this info was new knowledge?

What aspect of this info was reinforced information?

Part 2- Experience with New Technologies

Using the following words Very familiar, somewhat and Not Familiar

Describe your familiarity with the following tools:

1. The Blackboard Virtual Classroom.

2. Virtual reality Sites e.g. Second Life

3. Web 2.0 tools e.g. Wikis, Blogs, RSS Feeds

4. Podcasts Collaborative work tools - discussion boards, listservs

5. Social networking sites - facebook, twitter

6. Would you like to become familiar with any of these technology tools? Which?

7. Which do you think would be most useful in your role as a doctoral student? And why?

8. Which do you think may have pedagogical value for you as a learner? 


\section{Biographies}

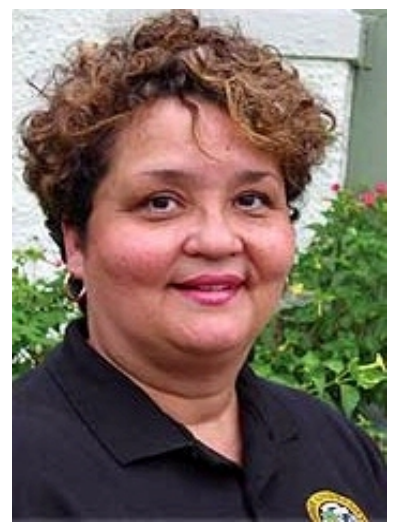

Dr. Elizabeth Moore Rhodes is a 2003 graduate in Educational Technology from Pepperdine University. She earned a Master of Arts degree from the University of Michigan and a Bachelor of Arts from Xavier University of Louisiana. She currently serves as an Assistant Professor at the Southeastern Louisiana University. While teaching at Southeastern, she has served as Director of the Center for Educational Services and Research in the College of Education and Human Development. Dr. Rhodes has also served in several capacities at Xavier University of Louisiana; as Director of Distance Learning, School/University Liaison in the Center for the Advancement of Teaching, Director of Student Teaching and as Assistant Professor in the Division of Education.

Throughout her career Dr. Rhodes has authored and co-authored numerous articles on diversity and education, minority teacher recruitment and technology in education. During her career, she has been awarded no fewer than five federal, state and private foundation grants enabling study of issues related to her research interests. She has served on the National Council of Accreditation of Teacher Education (NCATE) Board of Examiners, and the School Board of Sojourner Truth Academy and the Board of Commissioners for the Kenilworth Civic Improvement Association. She was designated a 2002 Role Model by the Young Women's Christian Association (YWCA). Dr. Rhodes also serves as Vice-President of LA Creole Research Organization and is a journal reviewer for their publication.

Dr. Lynette Ralph obtained a BA degree from the University of the

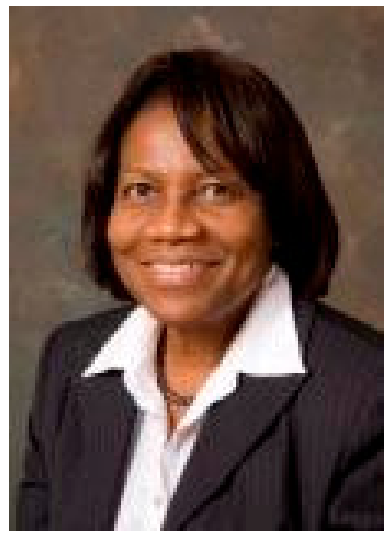

West Indies (U.W.I.), an MS (Library \& Information Science) from Pratt Institute, an MPA from University of Baltimore, and a Ph.D in Information Science from Nova Southeastern University. Lynette currently serves as Assistant Library Director at Southeastern Louisiana University (Southeastern). Prior to joining Southeastern, Lynette served as Associate Director for Public Services at Mercer University, and Associate Director for Access Services at University of Maryland Health Sciences Library. Lynette's areas of interests include Library Administration, emerging technology, and effective and innovative methods of delivering library services. She has published in several journals including College and Undergraduate Research Libraries, Journal of Information, Information Technology, and Organizations and Electronic Journal of Academic and Special Librarianship. 